\title{
Tourism planning and competitiveness in Ecuador
}

\author{
Vega Falcón Vladimir \\ Universidad Regional Autónoma de los Andes, UNIANDES \\ 284, Avenue E30, Quevedo, Riobamba, Ecuador - 060150 \\ ORCID: https://orcid.org/0000-0003-140-4018 \\ Navarro Cejas Mercedes \\ Universidad Regional Autónoma de los Andes, UNIANDES \\ 284, Avenue E30, Quevedo, Riobamba, Ecuador - 060150 \\ ORCID: https://orcid.org/0000-0003-4377 \\ Cejas Martínez Magda Francisca \\ Universidad Nacional de Chimborazo, UNACH 89 \\ Avenue Antonio José de Sucre Riobamba Ecuador - 060150 \\ ORCID: https://orcid.org/0000-002-0618-3608 \\ Mendoza Velazco Derling José* \\ Universidad Nacional de Educación, UNAE \\ 54 Street Chuquipata, Azogues, El Cañar, Ecuador - 030154 \\ ORCID: https://orcid.org/0000-0001-8275-3687 \\ E-mail: derling.mendoza@unae.edu.ec
}

\begin{abstract}
In the current economic scenario, tourism management emerges as one of the most dynamic activities of global capitalism. Its importance is appreciated in the contribution to the generation of wealth, according to the World Tourism Organization. In this context, transnational capital has forcefully penetrated with into touristic activity. However, the resulting effects in terms of sustainability have not been favorable. Ecuador has not escaped this dynamic, even though the Ministry of Tourism itself establishes the necessary harmony between this economic activity and sustainable development. Therefore, the work presented in this study, aims to analyze the dynamics of tourism planning and competitiveness in Ecuador. The study was developed under the paradigm of qualitative research, through an interpretive design of a literature review. The data was collected from different sources and checked by the researchers through a data triangulation method. The results show that Ecuador is a country with enormous potential to develop a diverse and attractive tourism market. The literature review made it possible to build a theoretical framework of reference, raising awareness about the importance and need of strategic planning for the development of a tourist destination. It also showed the basic structure of the analysis of the competitiveness of the company and addressing the issue through of an actual Ecuadorian case.
\end{abstract}

Keywords: Tourism, tourist competitiveness, strategic planning, touristic marketing, tourism planning.

\section{Introduction}

Ecuador is a country with enormous natural and cultural treasures and vast tourism potential. The amazing diversity of its four regions has resulted in hundreds of thousands of species of flora and fauna. Ecuador is considered one of the 17 countries with the highest biodiversity in the world. It has an array of unique historical attractions such as Quito, amazing culinary treats and a diversity of cultures and traditions which are worth experiencing. Like any business, however, tourism requires effective marketing. Nowadays, the importance of marketing in business success is well recognized. Entrepreneurs are increasingly aware that not all customers in a given market can be satisfied, but the target audience to which the business effort is intended to be focused must be carefully selected. This leads to the concept of segmentation. Traditionally, the tourism industry has perceived marketing and sales as being 
the same thing, and in reality, there is a very widespread misrepresentation that identifies advertising and sales promotion with marketing, which is, to some extent, understandable.

Advertising is just an element that is part of a general whole, therefore, if all aspects have not been taken into account when creating, designing and marketing the product or services, it is useless to make a large investment in advertising. The definition of customer satisfaction has been widely addressed, emphasizing various elements and diversifying its design. According to what has been stated by various authors, satisfaction corresponds to the perception of consumers, which is complex to measure objectively, especially in tourism given the nature of the product (González Uribe, Quiroz Rodríguez \& Gascón \& Diana, 2014). According to Martín and Díaz (2016), regardless of the type of process used to provide the services, the physical presence of the client during the service itself determines the rest of the decisions taken in the field of the operations strategies of the service companies. With regard to tourism marketing and services, it can be added that the influence displayed by the Internet before, during and after a tourist trip is progressive, since it makes it possible to plan the activities to be carried out during a trip including comments on it through the networks social (Carrera \& Vega, 2017).

In accordance with (Toro, Galán, Pico, Rozo \& Suescún, 2015), tourism planning is the basis of sustainable tourism development. It would not be logical to conceive of a tourism that takes care of the environment, respects the local culture and that simultaneously creates economic benefits for investors and communities, if it is not conceived in a planned way. The accelerated process of globalization in its multiple dimensions and expressions leads to the increasingly aggressive dependence between economies and societies of the world. In this scenario, tourism stands out as part of the ideal capitalist model to transfer capital to any region of the planet, where maximum profit is guaranteed, making it a conducive means for the transit of these regions towards inclusion in global circuits.

In 2017 the International Year of Sustainable Tourism for Development was celebrated, an event that deserves special attention in the search for new and multiple options in order to raise awareness of national states, destinations and travelers that must unite their efforts to achieve sustainable tourism development that protect the environment, conserve the cultural heritage of destinations, foster respect for local communities around the world and promote their articulation to the benefits of tourism activity within the global economy.

The situation described above forces the necessary reflection to explore alternatives that, from the potential of the territories, make it possible to take advantage of the opportunities that originate in the globalization process, without sharpening its intrinsic contradictions. Thus, in opposition to the Fordist tourism model associated with mass tourism, alternative tourism, associated with post-Fordism, emerges from the sustainability paradigm in the 1990s, following the Brundtland Report (UN, 1987) whose main objective was to find practical means to reverse the environmental and development problems of the world (Aguilar, Palafox \& Anaya, 2015).

According to the National Secretariat of Planning and Development, the new political project instituted since 2007 in Ecuador presents "the transition from an extractive, dependent and disorderly model at the territorial level, to a model of moderate sustainable use, using intelligently the available spaces, ensuring food sovereignty, considering population growth, protecting the environment, assessing risks from natural events, to be able to take precautionary and mitigation measures" (SENPLADES, 2009: 68).

The principles of sustainability refer to the environmental, economic and sociocultural dimension of tourism development, and an adequate balance must be reached between these three dimensions (Ministerial of Tourism at Ecuador, 2009). According to Gudinas "the new Ecuadorian Constitution includes several articles that directly or indirectly assume the paradigm of sustainable development. In addition, an innovative contribution to the vision of environmental sustainability is articulated through the Rights of Nature that involves a 
biocentric turn and proposes new forms of environmental assessment and articulation of indigenous knowledge" (Gudinas, 2009: 6).

In the last decade, Ecuador has gone through a process of political and social change, based on the current legal framework and on the Constitution. In this legal context that harmonizes a coexistence of preservation and respect for the human being and its ecosystem, the proposal of conscious tourism emerges, framed in the paradigm of Sustainable Development, from another perspective that motivates the reflection that other tourism is possible in the context of the new economic model, referred to in the 2008 Constitution, the National Plan for Good Living and the New Productive Matrix.

The different organizations present in the totality of the existing sectors in the economy have been thriving in their models of market orientation, as time has advanced and the level of competitiveness increases. This evolution can be seen in Figure 1.

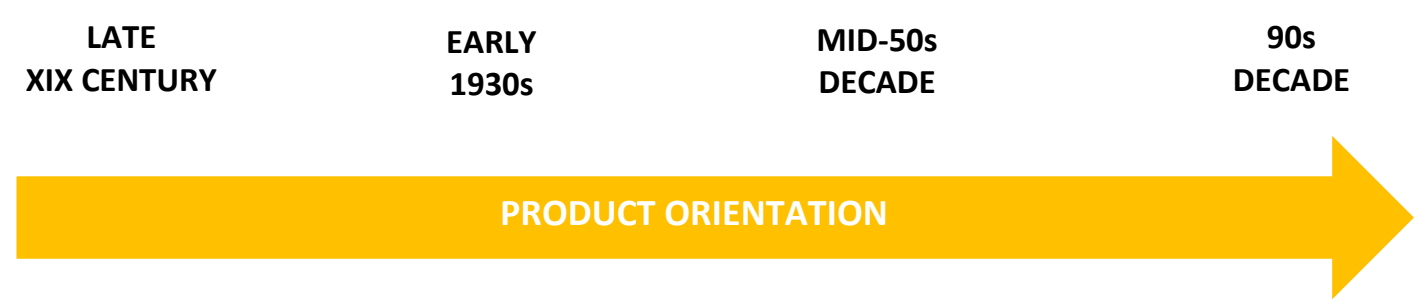

Some industries and organizations stay in the product orientation phase.

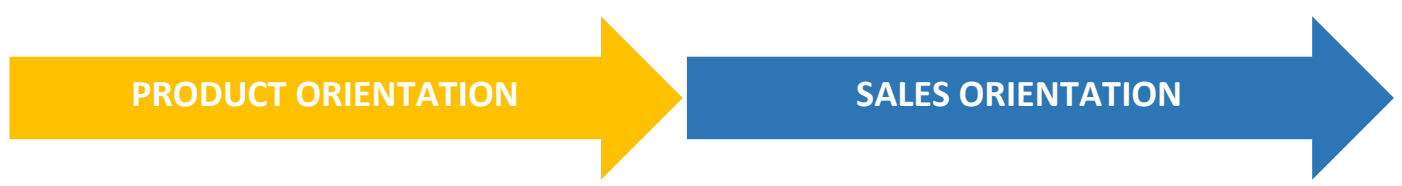

Some industries have progressed only to the sales orientation phase.

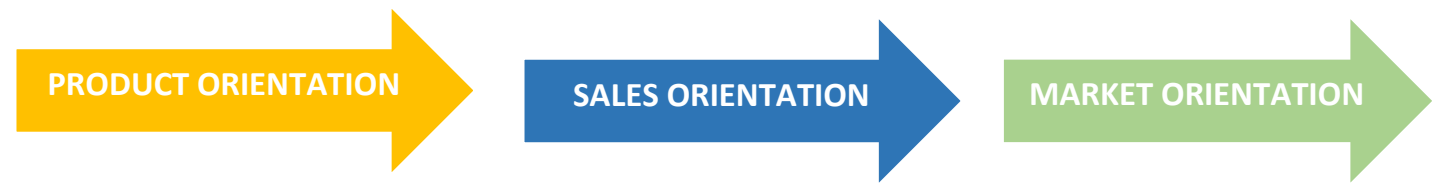

Many industries have evolved to the market orientation phase.

Figure 1. Marketing Evolution (Vega Falcón \& Vasallo Villalonga, 2017)

In the product orientation stage, organizations usually focused on the quality and quantity of offers, presuming that customers inquire and acquire well-prepared products at moderate prices.

The evolution and the increase of the competitiveness sent the orientation towards the sales, which carried out marketing actions to be able to sell all the excess of accumulated stock, but these were made from the point of view of the offer, since the organizations had yet to acquire an apposite business marketing approach. There are two essential requirements for all strategic planning: to be a sustainable planning and to be a consensual planning (Cañada, 2012). 
In this regard, a reflection of interest is as follows, one of the ways that organizations use to reduce their negative impacts and give back to society the profits they get through it is the application of the theory of corporate social responsibility. This reality also affects the tourism sector, which causes a strong impact on society and the environment. For this reason, organizations that operate in the tourism sector need to develop their activities contributing to the development of sustainable tourism (Lyra \& De Souza, 2015).

\section{External competitiveness analysis}

The main defining forces of the macroenvironment are: demographic, economic, natural, technological, political and cultural. Demography is a key factor, since the population constitutes the markets. It is essential to know demographic variables such as population size, age, sex, race, occupation, location, density, migration trend, birth, marriage or mortality rates, among others. The world population shows an explosive growth rate, since it has gone from almost 1 billion in the year 1800 to more than 6 billion in the year 2000, and on October 30, 2011 it reached 7 billion (Institute of Applied Ecology and Ministry of the Environment of Ecuador, 2007).

According to (United Sates Census Bureau, 2017), the world population on June 11, 2017 amounted to approximately 7, 396, 674, 000 inhabitants. The United Nations estimates that 10 billion people will be reached in 2050 and 11.5 billion in 2150 . When this figure is reached, it is believed that the world population could stabilize (although it is a fairly optimistic hypothesis). Thus, the population problem is not only the volume it reaches (figure 2), but how it is distributed across the different continents. By 2025, a distribution of the population is expected to be very different from the current one, concentrating $75 \%$ in Asia, $18 \%$ in Africa, $18 \%$ in Latin America and $6 \%$ in Europe. These figures have given what not only to companies think, but they have raised great concern among governments and social groups from all over the world.

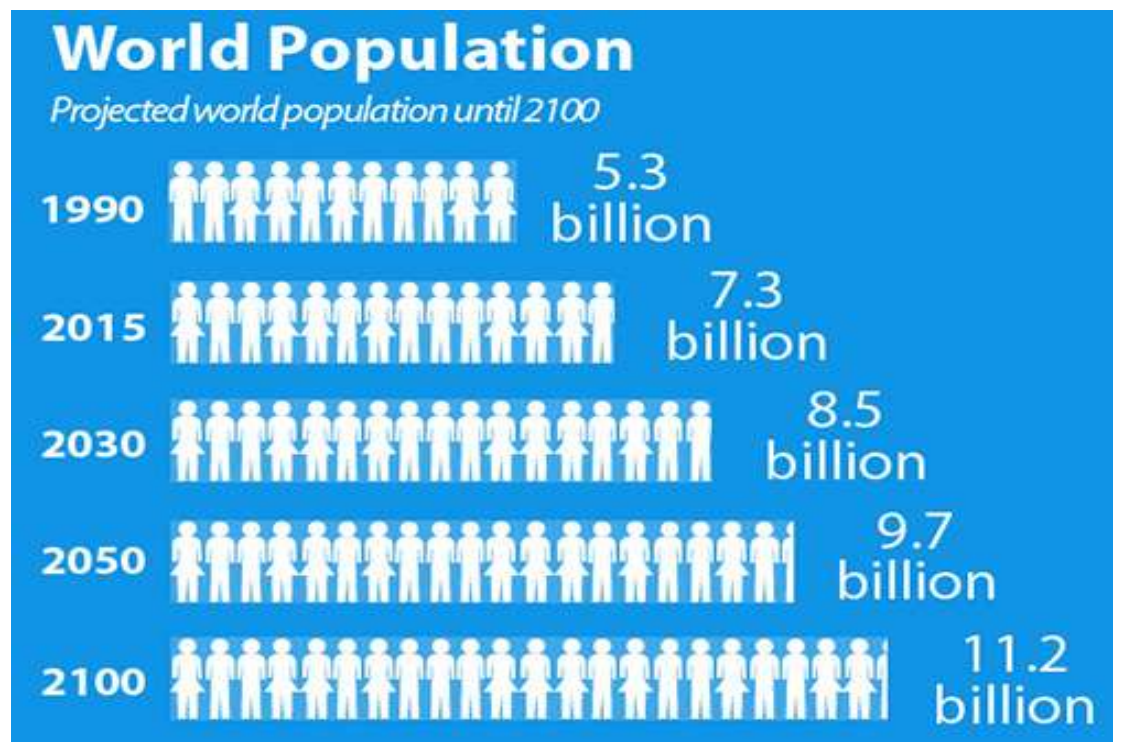

Figure 2. United Nations Department of Economic and Social Affairs.

Sixty percent of the world's population lives in Asia (4,400 million), 16\% in Africa (1,200 million), $10 \%$ in Europe (738 million), 9\% in Latin America and the Caribbean (634 million) and $5 \%$ remaining in North America (358 million) and Oceania (39 million). China (1.4 billion) and India (1.3 billion) continue to be the countries with the largest population. Both have more than 1 billion people and represent $19 \%$ and $18 \%$ of the world's population respectively (United Nations, 2017). 
For its part, the economic environment is formed by a series of factors that affect the purchasing power of consumers and their spending models. The purchasing power of individuals is a function of their income, price level, savings and the availability of credit that exists in the market. The deterioration of the environment is one of the main problems that tourism may face in the future. In recent decades, the population has been becoming aware of the effects of the often indiscriminate use of natural resources. It is very important that every company or tourist destination is attentive to technological innovations, so as not to be out of date with respect to the rest of the destinations present in the market and to the needs of consumers (OMT, 2018).

Regarding the political forces of the macroenvironment, it can be said that, over time, governments and supranational organizations have intervened and regulated many social and economic aspects, influencing and restricting the activities of organizations and individuals alike. Finally, with regard to cultural forces, it is appropriate to point out that a society is defined as a collective entity characterized by a set of beliefs and values common to all its members, which shape the worldview that determines the relationships of the individual with himself and with others (Coriolano \& Sampaio, 2013).

\section{Internal competitiveness analysis}

The microenvironment encompasses suppliers, competitors, market intermediaries, customers, bank and the community. The changes and events that occur in the environment of the suppliers, seriously affect the day to day of the company. For example, a company that organizes rafting descents on a river whose channel is regulated by a hydroelectric power plant, this becomes the supplier of the main means of the company's activity: water.

If the process followed by a potential customer to make a purchase decision is examined, the different groups of competitors that the company must have in mind are more easily located. It is clear that the company must face a wide variety of competitors, who compete to successfully meet the needs of the same target audience. Regarding market intermediaries, it can be noted that this group includes all those companies that help the company to promote, sell and distribute its goods to customers (Greenpeace, 2009). In relation to customers, it is appropriate to point out that the identification and specification of the target audience is one of the first steps for good marketing planning. No less important is the role that banks play, as sources of financing and the community, which generally interacts with business, sometimes positively and sometimes negatively (INEC, 2001).

\section{Methodology}

It is an interpretive case study as a qualitative research method, used to understand the reality of tourism planning and competitiveness, particularly in the case of Ecuador, and in trying to describe what happens in this specific case.

The research was based on an updated bibliographic review that has its roots on the accuracy of the source, the characterization of the analysis process carried out with the documentation and the construction of the results of the review in the form of a critical analysis. This achieved as a final product a study of the Ecuadorian case where a qualitative description was obtained, which implies consideration of the context in the framework of tourism planning and competitiveness (Hernandez, Fernandez \& Baptista, 2014).

Within the process of this case study, the authors began by selecting and defining the Ecuadorian case, to subsequently make a set of questions related to tourism planning and competitiveness that made it possible to focus on data collection. The data sources were located and these focused on primary publications (scientific articles resulting from research, reflection, review, case reports, books, and popular journals among others). This was in order to establish a point of view or position on the issue of tourism planning and competitiveness. 
Finally, the qualitative analysis was carried out and the present article was prepared as a synthesis of the study which was conducted.

\section{Results and Discussion}

\section{Tourism planning in Ecuador}

The purpose of the new global capitalism is its maximum expansion, in this drive it has the capacity to reach any social reality to expand the world market regardless of the consequences that are generated, the control of the economy and the change in social structures represent a clear characteristic of the globalization process, which is the main character of transnational companies. The mechanisms to achieve its objective are based on the control of capital, information, education and culture. The ability of tourism activity to transfer capital between all regions of the world is amazing. Just as urbanization and industrialization have their genesis, in the new form of capital-based production, tourism is a phenomenon that arises as a result of the development of productive forces.

Since the end of the last century, it has become one of the engines that drive economic development, being the industry with the highest growth rates worldwide, and therefore, one of the most important socio-economic phenomena of the twentieth and early twenty-first centuries as well, although at the beginning, it was only enjoyed by a small group of relatively well-off people, already by the seventh decade, it became a mass phenomenon for the more developed countries and has gradually become accessible to increasingly large groups (Vega \& Vasallo, 2017).

According to Santos (2018), the global travel industry grew faster in 2017 than in recent years. Tourists have regained confidence and gone on more international trips than ever before, despite terrorist attacks in various destinations. Undoubtedly, tourism has the potential to contribute significantly to broad-based inclusive growth and generate more opportunities for citizens, which is confirmed in the Americas, a context in which the Ecuadorian nation is framed, where travel and tourism represent $8.5 \%$ of Gross Domestic Product (GDP) and almost $10 \%$ of employment, and the region generated more than a quarter of the world's tourism revenue in 2016, illustrating the importance of the sector and its potential to contribute to the long term to fulfill the development objectives of the American region (UNWTO, 2018)

In Ecuador, the development and management of tourism activity has been present on the national agenda as a government policy. As for many other countries, this sector has been, in recent years, a fundamental axis in economic recovery, with important indicators such as inter alia, job creation, local and foreign investment projects, the development of hotel infrastructure and access roads, air connections, with domestic and international flights, which have favored the attraction of much needed foreign exchange to the national economy.

The variety of landscape, cultures, ethnic groups, flora and fauna, as well as the numerous possibilities for tourism, whether sun and beach, scientific, rural and mountain, adventure, urban or city, gastronomic, business, among others, make it an attractive destination. In this sense, from the national government they have structured in some cases, and updated in others, a series of programs and projects that govern the planning and tourism policy of the country, with defined short, medium and long term views. Among them, the Strategic Plan for the Development of Sustainable Tourism for Ecuador (PLANDETUR 2020).

The PLANDETUR 2020, seeks to consolidate sustainable tourism as one of the driving axes of the Ecuadorian economy, taking advantage of its competitive advantages and investing in tourist facilities, generating adequate management of territories and product lines. Drafted through a participatory process by the Tourism \& Leisure Advisory Services company hired by the Ministry of Tourism, and financed by the Inter-American Development Bank (IDB), it aims to strengthen the conditions of the national offer and promote local development that generates Equitable opportunities in the framework of Good Living. This new development project would 
replace the Tourism Competitiveness Plan of Ecuador, prepared in 1998. With the identification of 6 axes -governance, destination development, marketing, training, investment promotion and transversal measures-, 22 programs and 78 emblematic projects, organized in four chapters, this document became an important starting point for the sector, which would guide its actions on a time horizon until 2020.

For its part, PIMTE 2014, (Ministry of Tourism of Ecuador, 2009) is oriented to position Ecuador as a reference tourist destination worldwide with the aim of increasing international arrivals and internal displacements, which generate the entry of foreign exchange to the national economy in the first case. In the second case, there is the generation of jobs, equity in the distribution of income, the orientation to quality in the service to tourists and the general revitalization of the tourism production chain are promoted, with the establishment of a social, solidary and sustainable economic system. In the case of the National Program of Tourist Destinations of Excellence (2014), the main objective is to enhance the state competitively through four components, namely, the tourism offerings of Ecuador through the consolidation and development of prioritized routes, circuits, destinations and tourist attractions in order to contribute to excellence for the tourism sector.

For its part, the National Program for Tourism Excellence (2014), is proposed to improve the quality of tourism services, through the implementation of concrete actions and projects such as the development of quality regulations and protocols; the implementation of certifications and incentives; the formation and training of human talent; the investigation of new models and trends in tourism management and development and the management and awareness of the population towards a culture of innovation and excellence. (MINTUR, 2015). The natural and social demographic characteristics of Ecuador make it a country with real possibilities for tourism development and growth. The interaction of a privileged geography, great cultural heritage, archaeological and historical monuments, are just some attractions, of the many that generate interest.

In this regard, the United Nations, in the framework of the Sustainable Development Goals (2015-2030), recognizes in Goal 8 the need to promote sustained, inclusive and sustainable economic growth, full and productive employment and decent work for all. It should be noted that Zurab Pololikashvili, Secretary General of the World Tourism Organization (UNWTO) at the inauguration of the 2018 edition of the ITB, the Berlin tourism fair, pointed out that education, simultaneously with job creation, innovation and technology, security, sustainability and climate change are essential aspects that tourism must develop to consolidate its contribution to sustainable development and the 2030 Agenda (World Tourism Organization, 2018).

The UNWTO, in its Global Code of Ethics for Tourism (UNWTO, 2018), which, while it is true, is not a legally binding document, is a necessary reference to be taken into account and implemented by the actors of the activity. In its articles 2 and 3, tourism had referred to tourism as an 'instrument of professional and collective development' and as a factor in sustainable development. According to Castillo, Velázquez and Hernández (2015), tourism is one of the most promising economic resources on the planet, which contributes to the social, economic and cultural development of the countries. Consequently, tourism planning is of vital importance to ensure a correct revitalization of tourist destinations and an integral development of the territories, based on sustainability criteria, where the fulfillment of its three dimensions is evidenced: economically viable, ecologically admissible and socially equitable.

In Ecuador, public policies and government plans for the growth of the tourism sector do not give continuity to traditional models of consumerism, in which economic benefit indicators prevail over socio-cultural and environmental ones, but rather, modalities such as cultural, heritage and ecological tourism. In 2015, for example, just over two million tourists - nationals and foreigners - visited protected areas. The ecological tourism to these areas that cover $19 \%$ of the national territory constituted 35\% of the tourist GDP of the country (Cardoso, 2014). The national initiative of a new approach to Ecuadorian tourism management proposed in 2011 to 
tourism, within an ethical framework of responsibility with the environment, promotes the personal growth of both visitors and receiving communities. This type of tourism is even more ambitious than sustainable tourism, with precepts such as mutual respect, love of life and values of peace and friendship, in the essence of tourism practice.

Additionally, the virtue that can generate greater quality, hospitality and security to the visitor is recognized, while both he or she and the host share an experience that combines the natural pleasure generated by the practice of tourism with the search for the best welfare for all. In economic terms it could not be affirmed that tourism is as it is intended, the new Ecuadorian oil, but the efforts of the initiatives implemented are already beginning to be perceived. To date, it is the third non-oil productive sector that generates more foreign exchange, which contributes to reducing inequities and serves in improving the quality of life, generating employment, rest, recreation and new opportunities. And these are not only for international tourism, but conceivably grants access to travel and rest for most Ecuadorians, beyond the decree of frequent national holidays, and the construction of first-order access roads, with the presence of tourist stops in strategic locations. The conscious tourism in Ecuador is directed to an ethical and sustainable activity that can produce a life-transforming experience.

\section{Conclusions}

The qualitative analysis carried out in the present study, as well as the existing literature on the subject, demonstrate that the development of the tourism sector in its Fordist modality, is identified with neoliberal globalization and therefore, stands as a model of capital accumulation with all the implications and externalities of the system, generally impacting negatively on the populations of the localities where it is implanted, causing social exclusion, appropriation of the territory and impact on the environment and great benefits to the capitalists who are usually foreigners.

In Ecuador, despite the fact that current tourism policies covered by the constitutional framework advocate among its priorities the implementation of conscious tourism, within the economic development model, the dominant tourism model continues to be strengthened with the support of government agencies, and one of these investments is the Hotel Royal Decameron Mompiche. This demonstrates that before social and environmental sustainability, primacy is in the economic realm, which reveals a frank contradiction between instituted principles and their decontextualized practices.

The legal and public policy planning gap creates a poorly articulated and invisible space of actors that derives at the same time in an unordered tourist activity, without complying with the established regulations. Therefore, local communities are exposed to the depredation of their territories as an object of capitalist reproduction, making impossible the opportunities of sustainable development wielded by national and international institutions, revealing in their maximum expression the official discourse before the empirical evidence of reality.

Universally, there is an increase in awareness about the importance and need for planning and competitiveness for the development of a tourist destination, in which context the main defining forces of the macro environment are demographic, economic, natural, technological, political and cultural. Ecuador is a country with a formidable potential for the development of tourism with varied domestic destinations, under a socially inclusive, participatory and committed approach to accessible, diverse and attractive tourism. It is also supported by programs and projects that govern the country's tourism planning and policy, and although it has not yet reached the desired levels in the context of tourism competitiveness, the wills and initiatives undertaken are already beginning to be appreciated, being currently the third non-oil productive sector that creates more foreign exchange for the nation. 


\section{References}

Aguilar, A., Palafox A. \& Anaya, J. (2015). El turismo y la transformación del paisaje natural. Noésis. Revista de Ciencias Sociales y Humanidades, 24,(47), 19-20. Available online at: https://dialnet. unirioja.es/servlet/articulo?codigo $=5101979$ [Accessed July 2019]

Asamblea Nacional Constituyente de Ecuador. (2008). Constitución de la República del Ecuador. Available https://commons.wikimedia.org/wiki/File:Constituci\%C3\%B3n_de_Ecuador_2008_Logo.svg. [Accessed July 2019]

Cañada, E. (2012). Perspectivas del Turismo Comunitario: cómo mantener vivas las comunidades rurales. En El turismo en el inicio del milenio: Una lectura crítica a tres voces: Madrid.

Cardoso, C. (2014). Sosteniendo al Turismo o Turismo Sostenible. Estudios y Perspectivas en Turismo, 23(2), 376-395.

Carrera Calderón, F. A. \& Vega Falcón, V. (2017). Impacto de Internet en el sector Turístico. UNIANDES EPISTEME: Revista de Ciencia, Tecnología e Innovación, 4(4), 477-490. Available online at http://186.46.158.26/ojs/index.php/EPISTEME/article/view/828/326 [Accessed July 2019]

Castillo, L., Velázquez, D. \& Hernández, M. (2015). Turismo y exclusión social en Mahahual, Quintana Roo [II Congreso Coodtur Temas Pendientes y Nuevas Oportunidades en Turismo y Cooperación al Desarrollo] Universidad Rovira i Virgili Tarragona, España 18-11-2015 5ta. Ed pp. 63-7.

Coriolano, L. y Sampaio, C. (2013). Territorios solidarios de América Latina y turismo comunitario en rebote a los mega emprendimientos transnacionales. Revista Iberoamericana de Turismo - RITUR, Penedo, 3(1), 4-15. Available online at http://www.seer.ufal.br/index.php/ritur [Accessed July 2019]

Gascón, J. \& Diana, O. (2014). Turistas y campesinado: El turismo como vector de cambio de las economías campesinas en la era de la globalización. Madrid \& Tenerife: FTR \& Pasos edita.

González Uribe, E. G., Quiroz Rodríguez, J. \& Espinoza Mercado, Ó. (2016). Satisfacción del usuario en la industria hotelera como factor de competitividad. Mercados y Negocios, 11(2), 23-42.

Available online

at http://revistascientificas.udg.mx/index.php/MYN/article/viewFile/5155/4814 [Accessed July 2019]

Greenpeace. (2009). Los nuevos conquistadores Multinacionales españolas en América Latina. Impactos económicos, sociales y medioambientales: Madrid.

Gudinas, E. (2009). La Ecología Política del giro biocéntrico en la nueva Constitución de Ecuador. Revista de Estudios Sociales.

Hernández, R., Fernández, C. \& Baptista, P. (2014). Metodología de la Investigación. McGrawHill: México.

Institute of Applied Ecology and Ministry of the Environment of Ecuador. (2007). Guía del Patrimonio de Áreas Naturales Protegidas del Ecuador. Quito: ECOFUND, FAN, Darwin Net e IGM. Available online at: https://www.cuyabenolodge.com/national-parks/introduccionareas-protegidas-ecuador.pdf [Accessed July 2019]

Instituto Nacional de Estadística y Censos, INEC (2001). "Censo de Población y Vivienda 2001". Available online at: www.inec.gov.ec 
Lyra, F. R.,\& De Souza, M. J. (2015). Responsabilidad social corporativa en el sector turístico: un estudio de caso en el Parque Temático Beto Carrero World (Santa Catarina--Brasil). Estudios y Perspectivas en Turismo, 24(2), 264-279.

Martín Peña, M. L. \& Díaz Garrido, E. (2016). Fundamentos de dirección de operaciones en empresas de servicios. Madrid, España: ESIC.

Ministry of Tourism of Ecuador, (2009). Plan Integral de Marketing Turístico para el Turismo Interno de Ecuador PIMTE 2014. Quito: Tourism \& Leisure Advisory Services. Available online at http://www.competencias.gob.ec/wp-content/uploads/2017/06/c.-2014.-PLAN-INTEGRALMARKETING-TURISTICO.pdf [Accessed July 2019]

Ministry of Tourism of Ecuador. (2015). Plan Integral de Marketing Turístico para el Turismo Interno de Ecuador PIMTE 2016. Quito: Tourism \& Leisure Advisory Services.

National Program of Tourist Destinations of Excellence (2014), Quito: Ecuador.

OMT. (2018). World Tourism Organization and Organization of American States. doi: https://doi.org/10.18111/9789284419685. [Accessed July 2019]

Plan Estratégico de Desarrollo de Turismo Sostenible para Ecuador PLANDETUR 2020. Quito, Ecuador.

Santos, M. (2018). A natureza do espaço: técnica e tempo - razão e emoção. São Paulo: Hucitec

Secretaría Nacional de Planificación y Desarrollo, SENPLADES, (2009). Plan Nacional del Buen Vivir 2009- 2013. Available online at: http://www.planificacion.gob.ec/wpcontent/uploads/downloads/2012/07/Plan_Nacional_para_el_Buen_Vivir.pdf [Accessed July 2019]

Sustainable Development Goals (2015-2030). Available at: https://una-gp.org/the-sustainabledevelopment-goals-2015-2030/[Accessed July 2019]

Toro, G., Galán, M. L., Pico, L. A., Rozo, E. \& Suescún, H. (2015). La planificación turística desde el enfoque de la competitividad: caso Colombia. Turismo y Sociedad, XVI, 131-185. doi: http://dx.doi.org/10.18601/01207555.n16.09 [Accessed July 2019]

Tourism Highlights, UNWTO. (2018). International Tourism Trends 2017. Available at: https://www.e-unwto.org/doi/pdf/10.18111/9789284419876 [Accessed July 2019]

United Sates Census Bureau. (2017). Naciones Unidas. Available online at: http://www.un.org/es/sections/issues-depth/population/index.html

Vega Falcón, V. \& Vasallo Villalonga, Y. (2017). Planificación y competitividad turística: caso ecuador. Quito: El Siglo. Available online at http://marketing-jade.blogspot.com/2013/08/laevolucion-delmarketing-hasta-la.html [Accessed July 2019] 